\title{
The role of timing, duration, and frequency of inundation in controlling leaf litter decomposition in a river-floodplain ecosystem (Tagliamento, northeastern Italy)
}

Received: 17 May 2005/ Accepted: 27 September 2005/Published online: 20 October 2005

(C) Springer Verlag 2005

\begin{abstract}
Despite growing recognition of the importance of a natural flow regime in river-floodplain systems, researchers struggle to quantify ecosystem responses to altered hydrological regimes. How do frequency, timing, and duration of inundation affect fundamental ecosystem processes such as leaf litter decomposition? Along the semi-natural Tagliamento River corridor, located in northeastern Italy, we employed in situ experiments to separate effects of different inundation components on breakdown rates of black poplar (Populus nigra). We used a litter-bag method with two different mesh sizes to investigate how fungi and macroinvertebrates influence leaf breakdown rates. Ten treatments, each representing a specific combination of duration and frequency of inundation, were deployed in two seasons (summer, winter) to mimic complex inundation patterns. After 30 days of exposure, mean percentage of remaining leaf litter (ash free dry mass) ranged between $51 \%$ (permanent wet) and $88 \%$ (permanent dry). Leaf breakdown was significantly faster in winter than in summer. Duration of inundation was the main inundation component that controlled leaf breakdown rates. Leafshredding macroinvertebrates played only a role in the permanent wet treatment. Fungal parameters explained the faster leaf breakdown in winter. Our study suggests that modifications of the inundation regime will directly modify established decomposition processes. Factors reducing duration of inundation will decelerate leaf breakdown rates, whereas a decrease in flow variation will reduce leaf breakdown heterogeneity.
\end{abstract}

Communicated by Christian Koerner

S. D. Langhans $(\varangle) \cdot K$. Tockner

Department of Limnology,

Swiss Federal Institute of Aquatic Science

and Technology (Eawag),

8600 Duebendorf, Switzerland

E mail: simone.langhans@eawag.ch

Tel.: + 41448235157

Fax: +41448235315
Keywords Ecosystem process - Flow regime · Hydrology $\cdot$ Leaf breakdown - Tagliamento

\section{Introduction}

A natural inundation regime is regarded as the key driver of river-floodplain ecosystems (Junk et al. 1989; Poff et al. 1997; Tiegs and Pohl 2005). The magnitude, frequency, duration, and timing of the inundation regime influence biotic communities and ecosystem processes, either directly or indirectly through their effects on other primary regulators (Hart and Finelli 1999; Hession et al. 2000; Tockner et al. 2000; Robertson et al. 2001). Modification of the inundation regime thus has cascading effects on the ecological integrity of riverfloodplain systems (Bunn et al. 2002).

In a wide range of aquatic and terrestrial environments, decomposition of plant litter is a very important process in ecosystem metabolism and a driving force in nutrient cycling (Wallace et al. 1997; Webster et al. 1999; Cleveland et al. 2004). Much research has been conducted to identify the controlling factors and underlying mechanisms of decomposition (e.g. Robinson and Gessner 2000; Shaw and Harte 2001; Austin 2002; Hieber and Gessner 2002). In wetlands (marshes, swamps, floodplains), the flow regime has been identified as the primary driver of decomposition processes (Molles et al. 1995; Glazebrook and Robertson 1999; Andersen et al. 2003). Drying and wetting define the physical nature of the decomposition environment (Tockner et al. 2000), alter litter quality (Harner and Stanford 2003), and change nutrient conditions (Robertson et al. 1999; Heffernan and Sponseller 2004).

However, major inconsistencies exist in inundationdecomposition relationships. Decomposition can be hindered by anoxic conditions due to standing-water conditions or sediment deposition (Cuffney and Wallace 1987; Chauvet 1988) or enhanced by physical (i.e. leaching or fragmentation by stream flow or alternating dry/wet cycles) and biological processes (i.e. microbial 
activity or invertebrate consumption) (Ryder and Horwitz 1975; Brinson 1977; Molles et al. 1995; Lockaby et al. 1996; Battle and Golladay 2001). Most field studies have used a gradient or a correlative approach (e.g. comparing leaf mass loss with flood duration), which limits the ability to elucidate causal mechanisms (e.g. Brinson 1977; Shure et al. 1986; Graça et al. 2001; Austin 2002). However, hydrologic manipulation experiments are often difficult to interpret because the duration, frequency, and timing of inundation are poorly defined (Lockaby et al. 1996). Microcosm experiments in the laboratory offer limited value because they do not reflect natural conditions (Day 1983; Hagvar 1988).

In the present study, we designed intensive in situ experiments to mimic complex inundation patterns that were once characteristic for many temperate floodplain rivers (Poff et al. 1997; Tockner et al. 2003). We asked two key questions: first, to what extent does duration, frequency, and timing (season) of inundation influence leaf mass loss? Second, what is the role of microbes (i.e. aquatic fungi) and aquatic and terrestrial macroinvertebrates in controlling rates of leaf litter decomposition under different inundation regimes? We hypothesize that a complex inundation regime maintains high heterogeneity in leaf litter decomposition at the river-floodplain scale.

\section{Methods}

\section{Study site}

In situ experiments were carried out in summer 2003 and winter 2004 along the braided reach of the Fiume Tagliamento, a seventh-order gravel-bed river in NE Italy $\left(46^{\circ} \mathrm{N}, 12^{\circ} 30^{\prime} \mathrm{E}\right)$ with a total catchment area of $2,580 \mathrm{~km}^{2}$. The corridor is fringed by continuous riparian woodland. Despite local water abstraction and a channelized downstream section, the river retains essentially pristine morphological and hydrological characteristics. The flow regime is highly dynamic with frequent flow pulses (sensu Tockner et al. 2000) throughout the year (Arscott et al. 2002; Van der Nat et al. 2002).

Our study was conducted in an island-braided reach (river-km 79.8-80.8; $135 \mathrm{~m}$ a.s.1.) where lateral riparian forests and vegetated islands supply the floodplain with allochthonous organic material. Populus nigra and five species of Salix dominate the vegetation (Karrenberg et al. 2003). Average standing stocks of deposited CPOM (mainly leaves) across different floodplain strata ranged from $<1 \mathrm{~g} \mathrm{~m}^{-2}$ ash free dry mass (AFDM) on bare gravel surface to $>1,000 \mathrm{~g} \mathrm{~m}^{-2}$ AFDM on vegetated islands and riparian forests. In aquatic habitats, average annual CPOM standing stock was $10 \mathrm{~g} \mathrm{~m}^{-2}$ AFDM (Van der Nat 2002). Detailed information on the catchment, the main study reach, and the water chemistry is provided by Ward et al. (1999), Tockner et al. (2003), and Kaiser et al. (2004). Water chemistry, air temperature, and relative humidity at the study site, measured during the experiments, are summarized in Table 1.

\section{Experimental treatment}

The experiment was conducted in a $200 \mathrm{~m}$ long rifflerun section of a $20-\mathrm{m}$ wide braided channel (detailed description: Paetzold et al. 2005). We used a randomblock design in which four blocks (ten treatments each) were established along the riffle-run section (Fig. 1). Each treatment represented a specific combination of duration and frequency of inundation. Therefore, the effect of duration and frequency could be analysed separately. To simulate wet/dry cycles, leaves enclosed in nylon bags were transferred manually from instream to terrestrial (wet to dry) positions and vice versa. To partition the effects of shredders and microorganisms, breakdown of leaves enclosed in fine mesh bags, which preclude shredder access, was compared with leaf breakdown in coarse mesh bags. The experiment was designed for 30 days to have a trade-off between considerable leaf breakdown and reduced flood risk
Table 1 Physico chemical characterization of the study site in summer and winter $(n=$ number of measurements, mean $\pm 1 \mathrm{SD})$

$N D$ not detectable

\begin{tabular}{|c|c|c|c|c|}
\hline \multirow[t]{2}{*}{ Environmental parameter } & \multicolumn{2}{|c|}{ Summer } & \multicolumn{2}{|c|}{ Winter } \\
\hline & $n$ & Mean & $n$ & Mean \\
\hline Air temperature (daytime) & 360 & $32.8 \pm 6.0$ & 380 & $5.9 \pm 6.0$ \\
\hline Air temperature (nighttime) & 360 & $19.0 \pm 2.8$ & 380 & $0.0 \pm 3.1$ \\
\hline Relative humidity $(\%)$ & 30 & $55.9 \pm 6.2$ & 30 & $66.6 \pm 12.5$ \\
\hline Water temperature $\left({ }^{\circ} \mathrm{C}\right)$ & 730 & $16.5 \pm 2.4$ & 730 & $9.0 \pm 0.7$ \\
\hline Flow velocity $\left(\mathrm{m} \mathrm{s}^{-1}\right)$ & 5 & $0.49 \pm 0.11$ & 7 & $1.05 \pm 0.11$ \\
\hline Specific conductance $\left(\mu \mathrm{S} \mathrm{cm}{ }^{-1}\right)$ & 5 & $492.0 \pm 1.6$ & 3 & $649.7 \pm 5.4$ \\
\hline $\mathrm{pH}$ & 5 & $8.0 \pm 0.0$ & 3 & $8.2 \pm 0.1$ \\
\hline Oxygen $(\%)$ & 5 & $72.7 \pm 11.4$ & 3 & $132.5 \pm 22.8$ \\
\hline Total inorganic carbon $\left(\mathrm{mg} \mathrm{l}^{-1}\right)$ & 4 & $28.5 \pm 4.0$ & 4 & $33.5 \pm 2.2$ \\
\hline Total organic carbon $\left(\mathrm{mg} \mathrm{l}^{-1}\right)$ & 4 & $1.6 \pm 0.2$ & 4 & $0.5 \pm 0.2$ \\
\hline $\mathrm{NH}_{4} \mathrm{~N}\left(\mu \mathrm{g} \mathrm{l}^{-1}\right)$ & 4 & ND & 4 & $4.0 \pm 2.0$ \\
\hline $\mathrm{NO}_{3} \mathrm{~N}\left(\mu \mathrm{g} \mathrm{l}^{-1}\right)$ & 4 & $531.2 \pm 54.3$ & 4 & $837.0 \pm 126.3$ \\
\hline $\mathrm{NO}_{2} \mathrm{~N}\left(\mu \mathrm{g} \mathrm{l}^{-1}\right)$ & 4 & $1.9 \pm 1.7$ & 4 & $10.0 \pm 1.5$ \\
\hline $\mathrm{PO}_{4} \mathrm{P}\left(\mu \mathrm{g} \mathrm{l}^{-1}\right)$ & 4 & ND & 4 & ND \\
\hline
\end{tabular}




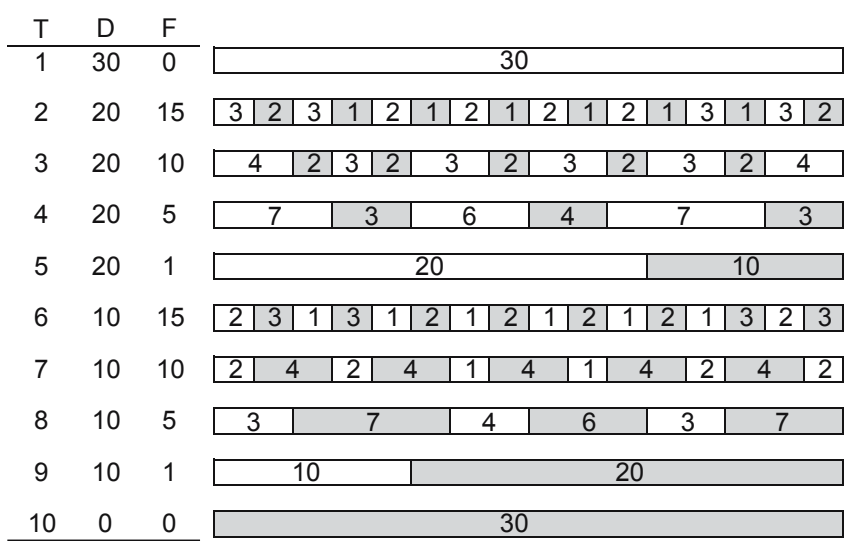

Fig. 1 Experimental design: ten treatments $(T)$ with different inundation regimes (white wet; grey dry conditions). Number days. $D$ duration of inundation (days), $F$ number of dry/wet cycles (frequency)

(Arscott et al. 2002). Water chemistry (nitrogen, phosphorus, and carbon species) and environmental parameters (temperature, conductivity, oxygen, vegetation cover, and gravel size) were similar among blocks.

\section{Sampling procedures}

Experiments were carried out in summer 2003 (28 July27 August) and winter 2004 (8 January-7 February). Leaves of Populus nigra (black poplar) were collected during senescence in autumn 2002 (summer experiment) and 2003 (winter experiment) directly from trees adjacent to the study site. Leaves were air-dried and stored under dry conditions. Portions of $5 \pm 0.25 \mathrm{~g}$ were weighed, moistened and packed in fine mesh $(0.5 \mathrm{~mm}$ mesh size) and coarse mesh (10 $\mathrm{mm}$ mesh size) nylon bags (Boulton and Boon 1991). Pairs of fine and coarse mesh bags were tied to iron bars and exposed in the stream bed and along the terrestrial shore corresponding to the experimental design (treatment). During the summer experiment, one coarse mesh bag out of 80 was lost because of vandalism. In both experiments, bags were retrieved after 30 days, placed individually in polyethylene bags and returned to the laboratory in cooling boxes.

\section{Laboratory procedures}

Leaves were carefully removed from the bags and gently rinsed with tap water to remove adhering debris and invertebrates. The remaining slurry was filtered through a $500-\mu \mathrm{m}$ mesh and the retained invertebrates were preserved in $70 \%$ ethanol. Fifteen leaf discs (diameter, $12 \mathrm{~mm}$ ) were cut from five different leaves (three discs per leaf) from each bag using a cork borer. Two sets of five discs were placed in a small polyethylene bag and frozen at $-20^{\circ} \mathrm{C}$ for ergosterol analyses. The ergosterol content of decaying litter, an indicator of fungal biomass, was estimated according to Gessner and Schmitt (1996). The third set of five leaf discs was put in a separate aluminium pan, and dried to constant mass at $60^{\circ} \mathrm{C}$ for $48 \mathrm{~h}$ together with the remaining decomposed leaves, before weighing to the nearest $0.1 \mathrm{~g}$. Total dry mass was determined by adding the dry mass of the leaf discs (times three) to the main bulk of leaves. Ground $0.5 \mathrm{~g}$ subsamples were ashed $\left(500^{\circ} \mathrm{C}, 6 \mathrm{~h}\right)$ to determine AFDM. Subsamples of initial leaves were processed in the same way to develop air dry mass to AFDM conversion factors.

The preserved invertebrates were sorted, identified to the lowest possible taxon, and counted. Taxa were assigned to functional feeding groups according to Tachet et al. (2000).

\section{Statistical analysis}

We used analyses of variance (ANOVA) with subsequent Scheffé's post-hoc tests to test for differences among treatment means (expressed as percentage of remaining AFDM; Wieder and Lang 1982), with block, season, duration, frequency, and mesh size as independent variables. If season and mesh size had significant influences on treatment means, we performed an ANOVA for each season and mesh size separately. Data were square root-arcsine transformed to meet ANOVA assumptions. The same ANOVA model was applied to analyse differences among mean fungal biomass (expressed as ergosterol).

Leaf breakdown rates $\left(k\right.$, day $\left.^{-1}\right)$ were calculated using an exponential decay model (Webster and Benfield 1986). We applied the ANOVA model as described above with $k$-values as dependent variable. As both analyses provided the same results, only data from percentage of remaining AFDM were presented.

Differences in macroinvertebrate abundance and shredder abundance among treatments 1,3 , and 7 were calculated using a MANOVA model. Wilks' $\lambda$ test statistics was used to assess treatment effects. Prior to the analyses, data were square root transformed to meet ANOVA assumptions.

The relationship between fungal biomass and remaining AFDM was determined by Spearman rank correlation.

All statistical analyses were performed using SPSS (ver. 11.0/SPSS Inc., IL, USA) with significance levels set at $P \leq 0.05$.

Our sampling design allowed us to statistically separate the effects of duration and frequency on leaf breakdown based on the calculation of partial residual plots (Ryan 1997). Depending on the treatment combination (duration/frequency), the parameter estimate value for the specific duration was subtracted to evaluate the effect of the corresponding frequency treatment, and vice versa. 


\section{Results}

Effect of timing (season)

Leaf breakdown (expressed as percent remaining AFDM after 30 days of exposure) was significantly higher in winter than in summer (ANOVA: $\left.F_{1,147}=124.16 ; P<0.001\right)$. In the summer experiment, mean percentage of remaining AFDM ranged 51.4$80.5 \%$ in coarse mesh bags and from 57.3 to $83.3 \%$ in fine mesh bags. In the winter experiment, 41.3 to $82.3 \%$ AFDM remained in coarse mesh bags and 49.2 to $88.4 \%$ in fine ones (Fig. 2).

\section{Effects of duration and frequency}

In the summer and winter experiment, leaf breakdown was fastest in permanently inundated and slowest in permanently dry treatments (both mesh sizes) (Table 2). In both seasons, duration had significant effects on remaining AFDM, while frequency was only significant in the summer experiment (Table 3). Subsequent posthoc tests showed that all duration treatments differed significantly from each other, whereas leaves inundated for 30 days broke down fastest, followed by leaves inundated for 20, 10 and 0 days. In summer, leaf breakdown from treatments with 1 dry/wet cycle was fastest differing significantly from treatments with 5 and with $0 \mathrm{dry} /$ wet cycles. Leaves which were exposed to 10 and $15 \mathrm{dry} /$ wet cycles broke down significantly faster than leaves, which underwent 0 changes (Scheffe's posthoc test). In summer, we also found a significant twoway interaction between duration and frequency (Table 3). Leaves from treatments with 1 or 15 dry/wet cycles broke down significantly faster when they were inundated 20 instead of 10 days, whereas leaves from treatments with 5 or 10 dry/wet cycles decomposed only slightly faster when inundated 20 days.

Analysing coarse mesh bags for both seasons separately, we found significant effects for duration but not for frequency (Table 4). Subsequent post hoc tests revealed that leaf breakdown differed significantly among all duration treatments with fastest rates during permanent inundation. Leaf breakdown in fine mesh bags was significantly influenced by duration and frequency in summer and by duration in winter (Table 4). In summer, leaves which were inundated 30 days decomposed fastest, those inundated 0 days slowest. Leaf breakdown in treatments with 10 and 20 days of

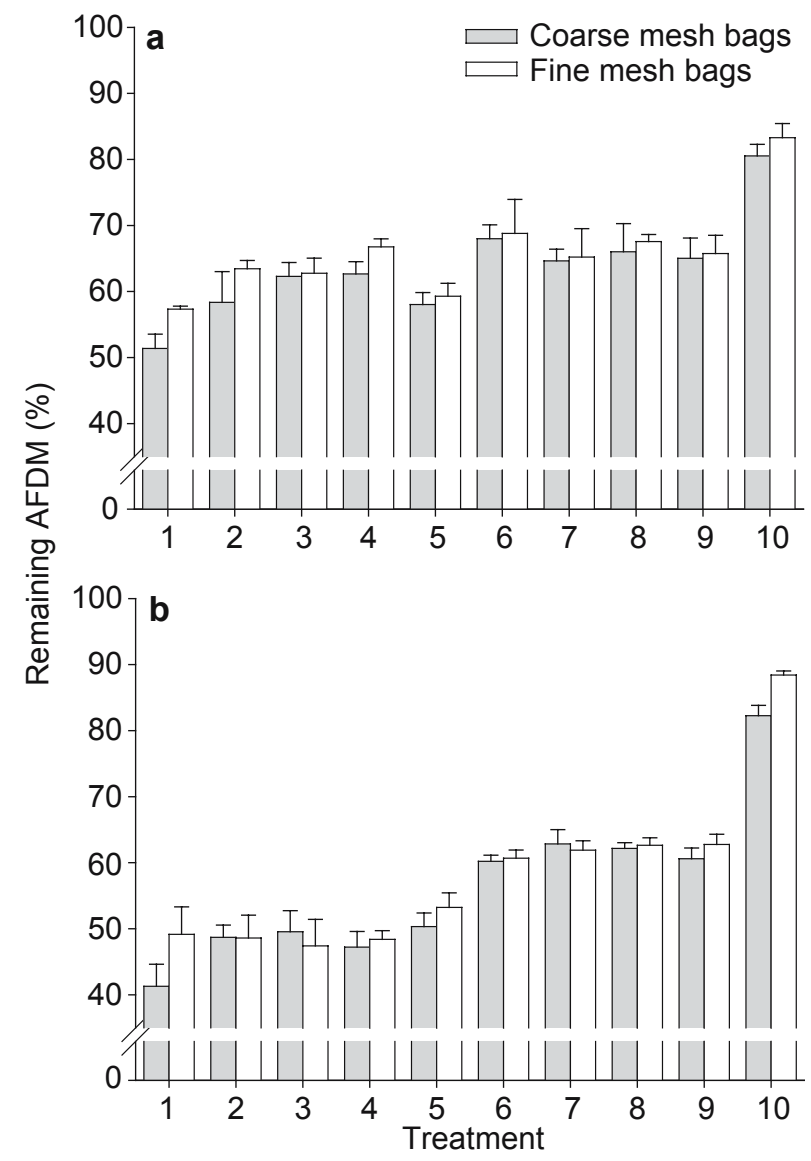

Fig. 2 Mass loss (mean $\pm 1 \mathrm{SE}$ ) of black poplar leaves in coarse and fine mesh bags with different hydrologic regimes in a summer and in b winter. (Treatments see Fig. $1 ; n=34$ )

Table 2 Summary of breakdown coefficients $\left(k\right.$ day $\left.^{-1}\right)$ for summer and winter experiments in coarse and fine mesh bags $(n=4$, mean $\pm 1 \mathrm{SE}$ )

\begin{tabular}{|c|c|c|c|c|}
\hline \multirow[t]{2}{*}{ Treatment } & \multicolumn{2}{|l|}{ Summer } & \multicolumn{2}{|l|}{ Winter } \\
\hline & Coarse mesh & Fine mesh & Coarse mesh & Fine mesh \\
\hline 1 & $0.0222 \pm 0.0010$ & $0.0185 \pm 0.0000$ & $0.0296 \pm 0.0014$ & $0.0238 \pm 0.0015$ \\
\hline 2 & $0.0181 \pm 0.0012$ & $0.0152 \pm 0.0005$ & $0.0240 \pm 0.0006$ & $0.0241 \pm 0.0012$ \\
\hline 3 & $0.0158 \pm 0.0005$ & $0.0155 \pm 0.0014$ & $0.0235 \pm 0.0011$ & $0.0250 \pm 0.0014$ \\
\hline 4 & $0.0156 \pm 0.0004$ & $0.0135 \pm 0.0001$ & $0.0251 \pm 0.0008$ & $0.0242 \pm 0.0005$ \\
\hline 5 & $0.0182 \pm 0.0005$ & $0.0174 \pm 0.0003$ & $0.0229 \pm 0.0007$ & $0.0210 \pm 0.0007$ \\
\hline 6 & $0.0129 \pm 0.0004$ & $0.0126 \pm 0.0010$ & $0.0169 \pm 0.0003$ & $0.0167 \pm 0.0003$ \\
\hline 7 & $0.0146 \pm 0.0002$ & $0.0143 \pm 0.0014$ & $0.0155 \pm 0.0006$ & $0.0160 \pm 0.0004$ \\
\hline 8 & $0.0139 \pm 0.0006$ & $0.0131 \pm 0.0002$ & $0.0158 \pm 0.0002$ & $0.0156 \pm 0.0003$ \\
\hline 9 & $0.0143 \pm 0.0009$ & $0.0140 \pm 0.0006$ & $0.0167 \pm 0.0005$ & $0.0155 \pm 0.0004$ \\
\hline 10 & $0.0072 \pm 0.0004$ & $0.0061 \pm 0.0001$ & $0.0065 \pm 0.0003$ & $0.0041 \pm 0.0001$ \\
\hline
\end{tabular}


Table 3 Values of $\mathrm{F}$ from two way analyses of variance (ANOVA) with percentage of remaining AFDM as dependent variable and block, mesh size, frequency, and duration as independent factors for summer and winter experiments ( $n=7980$ per season). Degrees of freedom for each effect are given in parentheses

\begin{tabular}{lcc}
\hline Effect & \multicolumn{2}{c}{ Remaining AFDM (\%) } \\
\cline { 2 - 3 } & Summer & Winter \\
\hline Block (3) & $3.56^{*}$ & 0.87 \\
Mesh size (1) & $8.41^{* *}$ & $8.71 * *$ \\
Frequency (3) & $4.67 * *$ & 1.42 \\
Duration (2) & $210.31 * * *$ & $530.98^{* * *}$ \\
Frequency $\times$ Duration (3) & $3.16^{*}$ & 1.87 \\
\hline$* P<0.05, * * P<0.01, * * * P<0.001$ & &
\end{tabular}

inundation duration was similar to each other. Frequency affected leaf decomposition as follows: leaves from treatments with 0 dry/wet cycles decomposed significantly slower than leaves from treatments with 1,10 , and $15 \mathrm{dry} /$ wet cycles. In winter, 30 and 20 days of inundation caused fastest leaf breakdown differing significantly from 10 and 0 days of inundation.

\section{Effects of macroinvertebrates and fungi}

In both seasons, leaf breakdown was significantly faster in coarse than in fine mesh bags (Table 3). Differences between coarse and fine mesh bags were greatest under permanent wet $5.97 \%$ of remaining AFDM in summer and $7.86 \%$ in winter) and permanent dry conditions $(2.75 \%$ in summer and $6.15 \%$ in winter). Mesh size was only found to have significant effects on leaf breakdown if permanent wet and dry treatments were included in statistical analyses. In both seasons, numbers of

Table 4 Values of $F$ from two way analyses of variance (ANOVA) with percent of remaining AFDM as dependent variable and block, frequency, and duration as independent factors for summer and macroinvertebrates were high, when, at the end of the experiment, bags were retrieved from wet conditions (treatments 1, 3 and 7) (Table 5). Where bags were retrieved from dry conditions (all other treatments), the number of macroinvertebrates was low $\left(<2\right.$ ind. $\left.\mathrm{bag}^{-1}\right)$. In summer, total macroinvertebrate and shredder abundance were similar in treatments 1,3 , and 7 (MANOVA: Wilks' $\left.\lambda=0.952, F_{4,16}=0.10, P=0.981\right)$. In winter, total macroinvertebrate and shredder abundance were higher in treatments 1 and 3 than in treatment 7, although not significantly different (MANOVA: Wilks' $\left.\lambda=0.348, F_{4,16}=2.78, P=0.063\right)$.

Initial fungal biomass $(0.011 \mathrm{mg}$ ergosterol per $\mathrm{g}$ AFDM) indicated minor fungal colonization of freshly collected leaves. The ANOVA model showed that the ergosterol content of leaves was significantly higher in winter than in summer (ANOVA: $F_{1,148}=9.58$; $P=0.002$ ). In summer, mesh size (ANOVA: $F_{1,69}=26.31 ; \quad P<0.001$ ) and duration (ANOVA: $\left.F_{2,69}=6.38 ; P=0.003\right)$ had significant effects on the ergosterol content of leaves, whereas frequency was only marginally significant (ANOVA: $F_{3,69}=2.60 ; P=0.059$ ). Fungal biomass was higher in coarse mesh bags, and treatments with permanent inundation were significantly different from all other treatments (Fig. 3a). However in winter, duration (ANOVA: $F_{2,66}=254.99 ; P<0.001$ ), frequency (ANOVA: $F_{3,66}=7.86 ; P<0.001$ ), and the interaction term of both (ANOVA: $F_{1,69}=3.50$; $P=0.002$ ), but not mesh size (ANOVA: $F_{1,66}=0.002$; $P=0.968)$ significantly influenced fungal biomass. Leaves inundated for 20 and 30 days showed significantly higher fungal biomass than leaves which were inundated for 10 days. Permanent dry leaves showed lowest fungal biomass. Treatments with 5 dry/wet cycles showed highest ergosterol values, significantly different

winter experiments, with coarse and fine mesh bags separated $(n=3940$ per season and mesh size). Degrees of freedom for each effect are given in parentheses

\begin{tabular}{lcccc}
\hline Effect & \multicolumn{2}{c}{ Summer experiment } & Winter experiment \\
\cline { 2 - 3 } & Coarse mesh & Fine mesh & Coarse mesh \\
\hline Block (3) & 1.64 & 2.02 & 0.78 & 0.87 \\
Frequency (3) & 1.45 & $3.82^{*}$ & 0.77 & 2.49 \\
Duration (2) & $113.53^{* * *}$ & $96.71^{* * *}$ & $38.58^{* * *}$ & $320.69^{* * *}$ \\
Frequency $\times$ Duration (3) & 2.27 & 1.44 & 1.29 \\
\hline
\end{tabular}

$* P<0.05, * * P<0.01, * * * P<0.001$

Table 5 Total macroinvertebrate abundance $\left(N \mathrm{bag}^{-1}\right)$ and shredder abundance $\left(N \mathrm{bag}^{-1}\right)$ in coarse mesh bags for summer and winter experiments $(n=4$, mean $\pm 1 \mathrm{SE})$

\begin{tabular}{llllll}
\hline & \multicolumn{2}{l}{ Summer } & & Winter \\
\cline { 2 - 3 } \cline { 5 - 6 } & Total abundance & Shredder abundance & & Total abundance & Shredder abundance \\
\hline Treatment 1 & $37.8 \pm 10.8$ & $20.8 \pm 8.2$ & $243.8 \pm 64.0$ & $23.0 \pm 2.7$ \\
Treatment 3 & $37.8 \pm 4.6$ & $17.8 \pm 3.9$ & $149.3 \pm 31.1$ & $19.3 \pm 3.2$ \\
Treatment 7 & $33.5 \pm 5.9$ & $16.5 \pm 5.2$ & & $42.0 \pm 8.3$ & $8.8 \pm 1.7$ \\
\hline
\end{tabular}




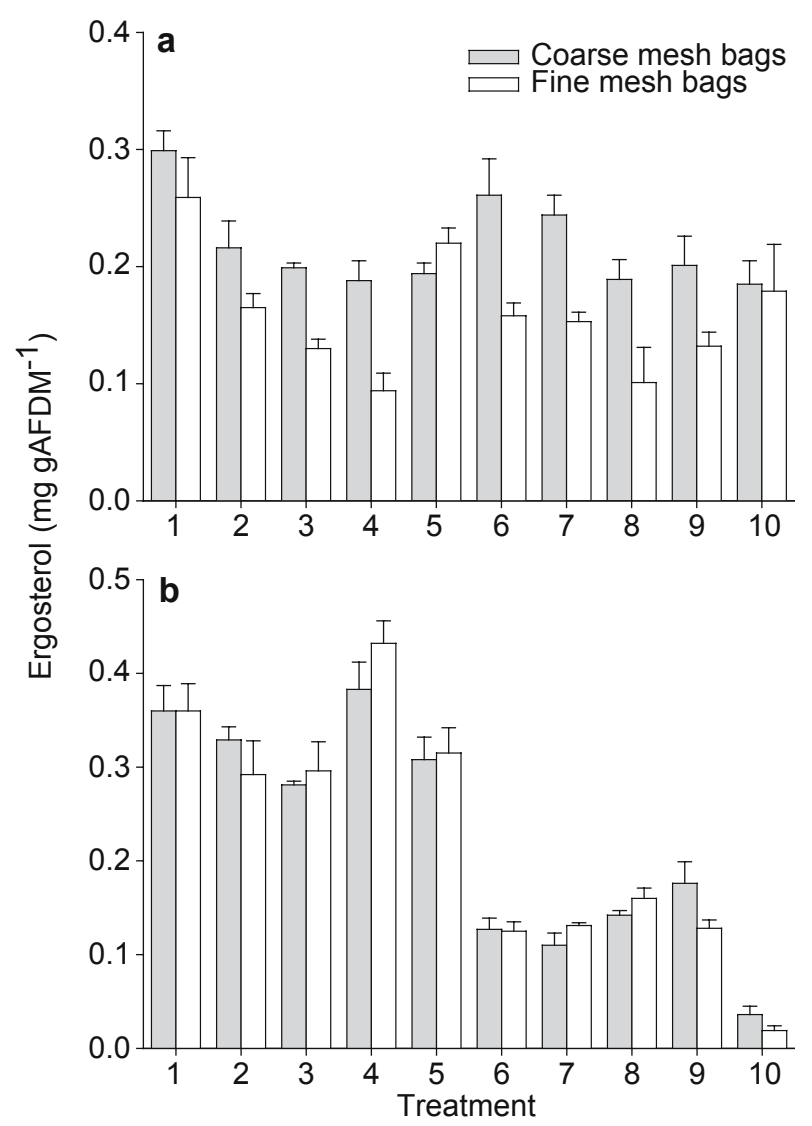

Fig. 3 Ergosterol content of leaves $\left(\mathrm{mg} \mathrm{gAFDM}^{-1}\right)$ in coarse and fine mesh bags with different hydrologic regimes in a summer and in b winter. (Treatments see Fig. $1 ; n=4$ )

from treatments with 0,10 , and 15 dry/wet cycles (Fig. 3b). The significant interaction between duration and frequency resulted from the fact that the increase of fungal biomass observed from 10 to 20 days of inundation was greater in treatments with 1 or 10 dry/wet cycles than in treatments with 5 or 15 dry/wet cycles.

In both seasons, leaf litter breakdown rate (percent of remaining AFDM) was significantly correlated with ergosterol concentration (Spearman rank correlation; summer, $\quad r=-0.335, \quad P=0.003$; winter, $r=-0.849$, $P<0.001)$.

\section{Discussion}

Effects of season and inundation regime

In our study, leaf litter breakdown varied considerably between seasons and among treatments. Leaves broke down faster during the winter experiment. Leaves under permanent inundated conditions lost almost $50 \%$ of its organic matter within 30 days, indicating a high decomposition rate compared to estimates from other temperate regions (e.g. Baldy et al. 1995; Pereira et al. 1998; Menéndez et al. 2003). Under dry conditions, leaf breakdown was similar to previously observed winter rates in the Tagliamento system (S.D. Langhans, unpublished data).

Leaf litter processing in aquatic and terrestrial habitats is the result of factors such as leaf-litter quality (Shaw and Harte 2001), temperature (Irons et al. 1994), relative humidity (Kuehn et al. 2004), dissolved oxygen (Chergui and Pattee 1988), dissolved nutrient concentrations (Robinson and Gessner 2000), and abundance and diversity of organisms responsible for decomposition (Dangles and Malmqvist 2004). In our study, oxygen, nutrient concentrations, velocity, and relative humidity were higher, and temperatures were lower in the winter experiment. Increased oxygen and relative humidity levels favour aerobic microbial respiration, and high concentrations of dissolved nutrients accelerate the processing of leaf litter (Robinson and Gessner 2000). Current velocity, ranging from $0.02-1.20 \mathrm{~m} / \mathrm{s}$, was found not to alter leaf breakdown rates (V.J.L. Ferreira et al., unpublished data). The effect of differing thermal regimes on leaf litter decomposition shows a clear tendency towards faster breakdown rates with increasing temperatures (e.g. Carreiro and Koske 1992; Menéndez et al. 2003). Apparently, in our experiments, the effect of temperature was most likely masked by other factors such as increased humidity and nutrient concentrations in winter.

Generally, mass loss from decaying leaf litter is faster in aquatic than in terrestrial systems because of enhanced leaching and microbial metabolisms (Molles et al. 1995). Similarly in our experiments, duration of inundation rather than frequency was the "master variable" controlling leaf breakdown in both seasons and mesh sizes. Our results correspond to those of Herbst and Reice (1982), who also found faster leaf breakdown rates in a permanent stream relative to a temporary and an intermittent stream (Tanninim and Daliya River, Israel). However, Battle and Golladay (2001) observed greatest decomposition under the most fluctuating hydrologic regime (Dougherty Plain, GA, USA). Their study was conducted under standing water conditions, where oxygen depletion may be a controlling factor. Oxygen was never a limiting factor and fine sediment deposition is not prevalent in the braided section of the Tagliamento River where we worked.

In both seasons, the effect of duration on percentage of remaining AFDM was particularly high if leaves were inundated only for few days. With increasing inundation time, the effect of duration decreased to zero. Frequency showed no correlation with percentage of remaining AFDM (Fig. 4). Our winter results are comparable with those of Lockaby et al. (1996) who suggested fastest decomposition under single inundation events. Mitsch and Gosselink (1993) stated that decomposition rates are most rapid under aerobic but moist conditions. These conditions existed in the hibernal humid climate in NE Italy, and intensified the effects we have found for 1 dry/wet cycle. During the hot and dry summer, only frequent dry/wet cycles could enhance decomposition. 
Fig. 4 The effect of a duration (days) and b frequency (dry/wet cycles) of inundation on percentage of remaining AFDM in summer $(n=79)$ and in winter $(n=80)$ experiments calculated on the basis of remaining AFDM(\%)

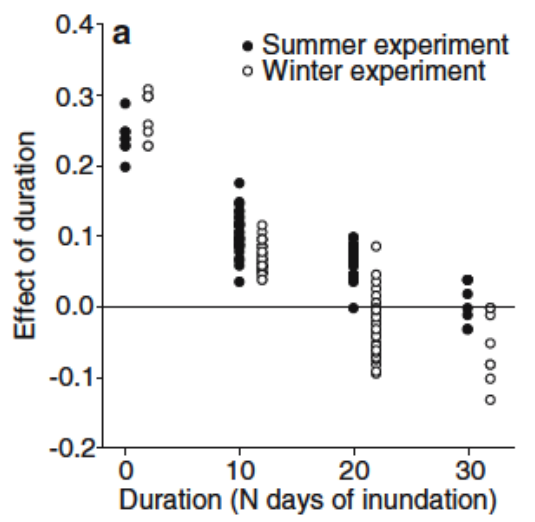

Effects of macroinvertebrates and fungi

Our second research question focused on the role of fungi and aquatic and terrestrial macroinvertebrates in controlling leaf litter decomposition under different inundation regimes. Shredding macroinvertebrates significantly increased leaf breakdown only during permanent wet conditions (on average by 3.3 to $16.0 \%$ ). Under permanent dry conditions, faster leaf breakdown in coarse mesh bags might have been caused by leaching because shredders were absent in these bags. Leaves in fine mesh bags seemed to be protected from heavy leaching by the mesh coverage. The minimal difference between coarse and fine mesh bags in all other treatments and both seasons suggested that dry/wet cycles were too frequent to establish feeding effects by macroinvertebrates on leaves. Physical abrasion must have played a minor role in the permanent wet treatment, otherwise, leaves in coarse mesh bags inundated for 20 and 10 days would have shown significantly faster breakdown rates than leaves in fine mesh bags.

In many aquatic ecosystems, fungi (hyphomycetes) play the predominant role in the microbial decomposition of leaves (Hieber and Gessner 2002). In contrast to bacteria, fungal assemblages are able to respond immediately to rewetting (Fierer et al. 2003). Therefore, alternating dry/wet cycles have only a small influence on the activity of fungal decomposers which might explain why duration was most important in our experiments. In a recent study, Kuehn et al. (2004) demonstrated that microbial activity on Phragmites australis leaves exhibited a duel periodicity with highest activity during night when relative humidity peaked. This finding suggests, why, in our case, fungal biomass was higher in winter than in summer. Even under terrestrial conditions, the humid winter climate in NE-Italy provided enough moisture for microbial activity. Therefore, increased microbial activity accounted for higher leaf breakdown rates during the winter. However, hot and dry summers (as in 2003) may reduce microbial activity, because leaching of polyphenols via rainfall and dew might be necessary before litter can be broken down (Boulton 1991). This explanation agrees with our finding that, if we considered leaf breakdown without feeding effects (fine mesh bags), significant duration effects in the moist season (winter), and significant duration and frequency effects in the dry season (summer) were found. Additionally, fungal biomass explained the effect of duration of inundation on leaf breakdown. However in winter, leaf breakdown behaved differently under the frequency treatments than fungal biomass. We suggest that frequency effects on fungal biomass are too small to influence leaf litter breakdown.

The relationship between hydrology and the decomposition process

In headwater streams, leaf litter enters the wetted channel during the autumnal litter fall period, thus input and processing overlap spatially and temporally. In floodplains, however, areas of production, storage and processing of leaves are spatially and temporally separated. Across a river-floodplain transect, standing stock of leaf litter biomass can change over four-orders of magnitude, from $<1$ (bare gravel surface) to about $1,000 \mathrm{~g}$ (vegetated islands) AFDM per $\mathrm{m}^{2}$ (Van der Nat 2002). While vegetated islands and the fringing riparian forest are the primary input and storage areas, aquatic habitats, in particular channels are the fastest processing areas. In such habitats, breakdown rates are several times faster compared to terrestrial areas. Most leaf litter is transferred from input/storage areas to river channels (fast processing areas) during periods with over bank flow. A human-regulated hydrologic regime often changes the duration, frequency, and magnitude of flow and flood pulses (Richter et al. 1997; Poff and Hart 2002). In flow-controlled systems, not only the amount of conveyed organic matter but also the transport distance and the breakdown dynamics are restricted.

\section{Concluding remarks}

Most attention on altered flow regimes has focused on their effects upon water quality and biota. There are only a few studies that rigorously tested for their impacts on ecosystem functioning (e.g. leaf litter decomposition) 
(Bunn et al. 2002). Results from our study showed that riverine floodplains display a remarkable heterogeneity in their ability to process organic matter, similar (albeit more complex) to riparian margins in small headwater streams (Hutchens and Wallace 2002).

Modifications of the inundation regime will directly (as shown in this study) and indirectly (i.e. by changing litter composition and quality) influence decomposition processes. Factors reducing duration of inundation will decelerate breakdown rates, whereas, a decrease in flow variation will reduce breakdown heterogeneity. If floodplain inundation changes the riparian vegetation will alter too (e.g. Busch 1995; Tiegs et al. 2005). This can result in dramatic consequences for leaf litter quality and quantity. In addition, the complex mosaic of terrestrial (e.g. bare gravel, islands, riparian forest) and aquatic (e.g. ponds, backwaters, channels) habitats, which ensure large spatial and temporal variation in litter dynamics, might be reduced to a less heterogeneous habitat composition. This decline in heterogeneity will weaken aquatic-terrestrial linkages by reducing the exchange of water, nutrients, and leaf litter among adjacent ecosystems (Gurnell et al. 2005).

Acknowledgements We are grateful to Simone Blaser and Claudio Cruciat for assisting in the field and in the laboratory, Richard Illi for conducting chemical analyses, and Bruno Tona for statistical advice. We also thank Scott Tiegs, Darren Bade, Stuart Findlay, Mark Gessner, and two anonymous reviewers for helpful advice that improved the manuscript. The study was supported by the EU funded project tempQsim (EVK1 CT2002 00112; http:/ www.tempqsim.net) and by BBW (No. 02.0072). The conducted experiments comply with the current laws of Italy.

\section{References}

Anderson DC, Nelson SM, Binkley D (2003) Flood flows, leaf breakdown, and plant available nitrogen in a dryland river floodplain. Wetlands 23:180 189

Arscott DB, Tockner K, Ward JV (2002) Geomorphic dynamics along a braided river corridor in the Alps (Fiume Tagliamento, Italy). Ecosystems 5:803 814

Austin AT (2002) Differential effects of precipitation on production and decomposition along a rainfall gradient in Hawaii. Ecology $83: 328338$

Baldy V, Gessner MO, Chauvet E (1995) Bacteria, fungi and the breakdown of leaf litter in a large river. Oikos 74:93 102

Battle JM, Golladay SW (2001) Hydroperiod influence on break down of leaf litter in cypress gum wetlands. Am Midl Nat 146:128 145

Boulton AJ (1991) Eucalypt leaf decomposition in an intermit tent stream in south eastern Australia. Hydrobiologia 211:123 136

Boulton AJ, Boon PI (1991) A review of methodology used to measure leaf litter decomposition in lotic environments: time to turn over an old leaf? Aust J Mar Fresh Res 42:1 43

Brinson MM (1977) Decomposition and nutrient exchange of litter in an alluvial swamp forest. Ecology 58:601 609

Bunn SE, Arthington AH (2002) Basic principles and ecological consequences of altered flow regimes for aquatic biodiversity. Environ Manage 30:492 507

Busch DE (1995) Mechanisms associated with decline of woody species in riparian ecosystems of the southwestern US. Ecol Monogr 65:347 370
Carreiro MM, Koske RE (1992) Effect of temperature on decom position and development of microfungal communities in leaf litter microcosms. Can J Bot 70:2177 2183

Chauvet E (1988) Influence of the environment on willow leaf litter decomposition in the alluvial corridor of the Garonne River. Arch Hydrobiol 112:371 386

Chergui H, Pattee E (1988) The impact of benthic invertebrates on the breakdown of poplar leaves in the network of a large European river. Arch Hydrobiol 113:15 25

Cleveland C, Neff JC, Townsend AR, Hood E (2004) Composition, dynamics, and fate of leached dissolved organic matter in ter restrial ecosystems: results from a decomposition experiment. Ecosystems 7:275 285

Cuffney TF, Wallace JB (1987) Leaf litter processing in coastal plain streams and floodplains of southeastern Georgia, USA. Arch Hydrobiol Suppl 76:1 24

Dangles O, Malmqvist B (2004) Species richness decomposition relationships depend on species dominance. Ecol Lett 7: 395402

Day FP (1983) Effects of flooding on leaf litter decomposition in microcosms. Oecologia 56:180 184

Fierer N, Schimel JP, Holden PA (2003) Influence of drying rew etting frequency on soil bacterial community structure. Microbial Ecol 45:63 71

Gessner MO, Schmitt AL (1996) Use of solid phase extraction to determine ergosterol concentrations in plant tissue colonized by fungi. Appl Environ Microbiol 62:415 419

Glazebrook HS, Robertson AI (1999) The effect of flooding and flood timing on leaf litter breakdown rates and nutrient dynamics in a river red gum (Eucalyptus camaldulensis) forest. Aust J Ecol 24:625 635

Graça MAS, Ferreira RCF, Coimbra CN (2001) Litter processing along a stream gradient: the role of invertebrates and decom posers. J N Am Benthol Soc 20:408 420

Gurnell AM, Tockner K, Edwards P, Petts G (2005) Effects of deposited wood on biocomplexity of river corridors. Front Ecol Environ 3:377 382

Hagvar S (1988) Decomposition studies in an easily constructed microcosm: effects of microarthropods and varying soil $\mathrm{pH}$. Pedobiologia 31:293 303

Harner MJ, Stanford JA (2003) Differences in cottonwood growth between a losing and a gaining reach of an alluvial floodplain. Ecology 84:1453 1458

Hart DD, Finelli CM (1999) Physical biological coupling in streams: the pervasive effects of flow on benthic organisms. Annu Rev Ecol Syst 30:363 395

Heffernan JB, Sponseller RA (2004) Nutrient mobilization and processing in Sonoran desert riparian soils following artificial re wetting. Biogeochemistry 70:117 134

Herbst G, Reice SR (1982) Comparative leaf litter decomposition in temporary and permanent streams in semi arid regions of Israel. J Arid Environ 5:305 318

Hession WC, Johnson TE, Charles DF, Hart DD, Horwitz RJ, Kreeger DA, Pizzuto JE, Velinsky DJ, Newbold JD, Gianfrani C, Clason T, Compton AM, Coulter N, Fuselier L, Marshall BD, Reed J (2000) Ecological benefits of riparian reforestation in urban watersheds: study design and preliminary results. Environ Monit Assess 63:211 222

Hieber M, Gessner MO (2002) Contribution of stream detritivores, fungi, and bacteria to leaf breakdown based on biomass esti mates. Ecology 83:1026 1038

Hutchens JJ Jr, Wallace BJ (2002) Ecosystem linkages between southern Appalachian headwater streams and their banks: leaf litter breakdown and invertebrate assemblages. Ecosystems 5:80 91

Irons JG, Oswood MW, Stout RJ, Pringle CM (1994) Latitudinal patterns in leaf litter breakdown: is temperature really impor tant? Freshw Biol 32:401 411

Junk WJ, Bayley PB, Sparks RE (1989) The flood pulse concept in river floodplain systems. Can Spec Publ Fish Aquat Sci 106:110 127 
Kaiser E, Arscott DB, Tockner K, Sulzberger B (2004) Sources and distribution of organic carbon and nitrogen in the Tagliamento River, Italy. Aquat Sci 66:103 116

Karrenberg S, Kollmann J, Edwards PJ, Gurnell AM, Petts GE (2003) Patterns in woody vegetation along the active zone of a near natural Alpine river. Basic Appl Ecol 4:157 166

Kuehn KA, Steiner D, Gessner MO (2004) Diel mineralization patterns of standing dead plant litter: implications for $\mathrm{CO}_{2}$ flux from wetlands. Ecology 85:2504 2518

Lockaby BG, Murphy AL, Somers GL (1996) Hydroperiod influ ences on nutrient dynamics in decomposing litter of a flood plain forest. Soil Sci Soc Am J 60:1267 1272

Menéndez M, Hernández O, Comín FA (2003) Seasonal compar isons of leaf processing rates in two Mediterranean rivers with different nutrient availability. Hydrobiologia 495:159 169

Mitsch WJ, Gosselink JG (1993) Wetlands, 2nd edn. Van Nostrand Reinhold, New York

Molles MC, Crawford CS, Ellis LM (1995) Effects of an experi mental flood on litter dynamics in the middle Rio Grande riparian ecosystem. Regul River 11:275 281

Paetzold A, Schubert C, Tockner K (2005) Aquatic terrestrial linkages along a braided river: Riparian arthropods feeding on aquatic insects. Ecosystems (in press)

Pereira AP, Graça MAS, Molles M (1998) Leaf litter decomposi tion in relation to litter physico chemical properties, fungal biomass, arthropod colonization, and geographical origin of plant species. Pedobiologia 42:316 327

Poff NL, Allan JD, Bain MB, Karr JR, Prestegaard KL, Richter BD, Sparks RE, Stromberg JC (1997) The natural flow regime: a paradigm for conservation and restoration. BioScience 47:769 784

Poff NL, Hart DD (2002) How dams vary and why it matters for the emerging science of dam removal. BioScience 52:659 668

Robertson AI, Bunn SE, Boon PI, Walker KF (1999) Sources, sinks and transformations of organic carbon in Australian floodplain rivers. Mar Freshw Res 50:813 829

Robertson AI, Bacon P, Heagney G (2001) The responses of floodplain primary production to flood frequency and timing. $\mathrm{J}$ Appl Ecol 38:126 136

Robinson CT, Gessner MO (2000) Nutrient addition accelerates leaf breakdown in an alpine springbrook. Oecologia 122: 258263

Richter BD, Baumgartner JV, Wigington R, Braun DP (1997) How much water does a river need? Freshw Biol 37:231 249

Ryan TP (1997) Modern regression methods. Wiley, New York, pp 145147
Ryder DS, Horwitz P (1975) Seasonal water regimes and leaf litter processing in a wetland on the Swan Coastal Plain, Western Australia. Mar Freshw Res 46:1077 1084

Shaw MR, Harte J (2001) Control of litter decomposition in a subalpine meadow sagebrush steppe ecotone under climate change. Ecol Appl 11:1206 1223

Shure DJ, Gottschalk MR, Parsons KA (1986) Litter decomposi tion processes in a floodplain forest. Am Midl Nat 115:314 327

Tachet H, Richoux P, Bournaud M, Usseglio Polatera P (2000) Invertébrés d'eau douce: systématique, biologie, écologie. CNRS Éditions, Paris

Tiegs SD, Pohl MM (2005) Planform channel dynamics of the lower Colorado River: 1976 2000. Geomorphology 69:14 27

Tiegs SD, O'Leary JF, Pohl MM, Munill CL (2005) Flood dis turbance and riparian species diversity on the Colorado River Delta. Biodivers Conserv 14:1175 1194

Tockner K, Malard F, Ward JV (2000) An extension of the flood pulse concept. Hydrol Process 14:2861 2883

Tockner K, Ward JV, Arscott DB, Edwards PJ, Kollmann J, Gurnell AM, Petts GE, Maiolini B (2003) The Tagliamento River: a model ecosystem of European importance. Aquat Sci 65:239 253

Van der Nat D (2002) Ecosystem processes in the dynamic Ta gliamento river (NE Italy). Dissertation, Swiss Federal Institute of Technology

Van der Nat D, Schmidt AP, Tockner K, Edwards PJ, Ward JV (2002) Inundation dynamics in braided floodplains: Taglia mento River, Northeast Italy. Ecosystems 5:636 647

Wallace JB, Eggert SL, Meyer JL, Webster JR (1997) Multiple trophic levels for a forested stream linked to terrestrial litter inputs. Science 277:102 104

Ward JV, Tockner K, Edwards PJ, Kollmann J, Bretschko G, Gurnell AM, Petts GE, Rossaro B (1999) A reference river system for the Alps: the 'Fiume Tagliamento'. Regul River 15:63 75

Webster JR, Benfield EF (1986) Vascular plant breakdown in freshwater ecosystems. Ann Rev Ecol Syst 17:567 594

Webster JR, Benfield EF, Ehrmann TP, Schaeffer MA, Tank JL, Hutchens JJ, D'Angelo DJ (1999) What happens to allochth onous material that falls into streams? A synthesis of new and published information from Coweeta. Freshwater Biol 41: 687705

Wieder RK, Lang GE (1982) A critique of the analytical methods used in examining decomposition data obtained from litter bags. Ecology 63:1636 1642 